\title{
CHESTERMAN, Andrew. Memes of Translation - The spread of ideas in translation theory. Amsterdam/Philadelphia: Benjamins Translation Library, 2016, 225 p.
}

Luciana Alves da Silva 1

${ }^{1}$ Universidade Federal do Ceará, Fortaleza, Ceará, Brasil

O livro Memes of Translation: The spread of ideas in translation theory, de Andrew Chesterman, foi publicado inicialmente em 1997. Uma edição revista foi publicada em 2016, com algumas correções e reformas fazendo referências às teorias mais recentes e abordando criticamente a versão anterior. A edição mais moderna inclui seções especiais ao final de cada capítulo, nas quais são apontados conceitos que se estabeleceram mais recentemente na área de pesquisa concernente à área do capítulo em questão. A obra propõe três maiores objetivos de ordem metateórica, teórica e prática: a proposição de uma espécie de quadro relacionando diversos conceitos sobre a tradução; Uma combinação entre a teoria normativa e a teoria prática; e a demonstração de que a teoria da tradução é útil e aplicável.

O livro inicia uma descrição da origem e do significado do termo teoria, tomando sua acepção como um modo de ver, um ponto de vista. No capítulo primeiro, Survival machines for memes (Máquinas de sobrevivência para os memes), a definição do conceito primordial do livro nos apresenta os memes como, precisamente, as ideias que se estabelecem a partir de uma determinada teoria. O conceito de meme foi emprestado da sociobiologia de Richard 
Dawkins em The Selfish Gene (1976), porque, assim como os genes, memes são ideias que se disseminam e se replicam, em todas as áreas do conhecimento. Memes são, portanto, unidades replicadoras. Chesterman conceitua cinco "supermemes" na área da tradução, cuja discussão já se estende há muito nos estudos tradutórios e, a partir dos quais, geram-se muitos outros. Os cinco supermemes conceituados no livro são Source-Target; Equivalence; Unstranlatability; Free vs. Literal; All-Writing-is-translation. (Texto-fonte e texto-alvo; Equivalência; Intraduzibilidade; Tradução livre vs. Tradução Literal; Todo texto é tradução)

A metáfora do texto-fonte e do texto-alvo é o primeiro supermeme. Acredita-se que as traduções não eliminam os textos originais, ou seja, os memes se replicam em uma metáfora genética de propagação, difusão, extensão e evolução. É como um movimento de A para B, que não elimina A. Essa ideia consagrou-se como um supermeme amplamente aceito nos Estudos da Tradução contemporâneos. A ideia de equivalência, no entanto, é considerada um supermeme em declínio. A noção de que um texto traduzido equivale ao original é abordada a partir de conceitos desenvolvidos por autores como Nida (1964), Jakobson (1994), Newmark (1981), House (1981) e Nord (1991). Muito além da preocupação simples com a igualdade, o conceito de Equivalência é dividido em funcional, estilística, semântica, formal (gramatical), estatística e textual. Chesterman ressalta que a Equivalência seria a 'perfeição', o que é, no entanto, inatingível na prática.

O mito da intraduzibilidade parte do pressuposto de que não é possível alcançar uma equivalência universal em forma e conteúdo. Assim também há o pensamento de que, na verdade, traduzir é uma impossibilidade, já que o todo não é traduzível. O que se justifica no argumento tradicional de Jakobson, de que poesia é um gênero intraduzível. Entretanto, algumas visões opostas a esse argumento foram descritas por Benjamin (1923), que aponta a convergência 
de todas as línguas e por Katz (1978) que afirma a possibilidade de se expressar uma mesma proposição em qualquer língua.

$\mathrm{O}$ argumento livre vs. literal considera o fato de que as traduções são realizadas na impossibilidade de uma equivalência perfeita sobre a forma do original e de que a tradução livre não é tradução, mas uma adaptação ou imitação. Assim, a tradução livre estaria atrelada a uma equivalência funcional enquanto a tradução literal se organiza em torno de uma equivalência formal. Para Barkhudarov (1993), no entanto, a escolha do tradutor por uma unidade de tradução menor teria como consequência um produto mais literal. Newmark (1981) defende que a tradução literal deve ser utilizada com maior frequência, sendo esse o único modo possível de se traduzir um conteúdo. A ideia de que toda escrita é um tipo de tradução refuta a teoria da intraduzibilidade, já que as palavras não pertencem a um único indivíduo, pois já foram utilizadas anteriormente. Da mesma forma, quando lemos um autor antigo em língua materna, também realizamos uma espécie de atualização, ou tradução intralingual.

Os memes de Chesterman existem nos três mundos propostos por Karl Popper (1978): O mundo físico, o mundo mental/ psicológico e o mundo dos produtos da mente humana. O Meme popperiano se organiza em qualquer área do conhecimento, de uma forma tal em que se tenha um problema e uma teoria é aplicada na tentativa de solucioná-lo. Para Andrew Chesterman, o meme tem se mostrado uma metáfora bastante produtiva. Apesar de os Estudos da Tradução não comportarem o termo meme dentre suas palavras-chave, Memes of Translation tem sido citado frequentemente por outros autores. Chesterman reconhece que o fato de que o meme ainda não seja utilizado de forma oficial nos Estudos da Tradução deve-se ao fato de que, em sua natureza, o conceito ainda suscita dúvidas sobre sua existência concreta ou apenas de ordem metafórica.

O capítulo 2, "The Evolution of translation memes" ( $A$ Evolução dos memes da Tradução), explica cada estágio dessa evolução, sen- 
do que a presente configuração de memes da tradução é uma 'amálgama de traços de memes precedentes ou complexo de memes' (40). O autor propõe uma descrição do desenvolvimento histórico dos Estudos da Tradução, que também pode ser compreendido através de seus principais memes e suas mudanças ao longo do tempo. As primeiras teorias tradutórias estão atreladas à Palavra de Deus, nas muitas teorias que envolvem a tradução da Bíblia e o constante zelo à palavra, na manutenção de sua literalidade. A linha temporal dos Estudos da Tradução também se estende aos pré-românticos alemães, além de Goethe e Schleiermacher, perpassa a importância da Linguística como ciência nos anos de 1960 e 1970, até chegar nos estudos mais modernos que passaram a considerar a tradução como comunicação de uma mensagem. A seção complementar da nova edição traz uma consideração do autor sobre a falta do desenvolvimento de uma teoria unificada da tradução, já que o foco principal dos Estudos da Tradução reside no próprio ato tradutório ou na avaliação de suas consequências.

O terceiro capítulo "From memes to norms" (Dos memes às normas) se fixa nas normas, ou seja, naqueles memes dominantes que guiam todos os procedimentos tradutórios, tanto do próprio tradutor quanto da comunidade que o avalia. Considerando que um tradutor tende a seguir as regras da sociedade e da comunidade de tradutores em que está envolvido, Chesterman distingue duas abordagens principais: a Normativa e a Prescritiva (aquelas que recomendam o que os tradutores devem fazer ou como as traduções idealmente deveriam ser). A proposição do autor é a de novas normas como alternativas àquelas designadas por Toury, cuja proposição tinha por base o estabelecimento de leis tradutórias e exerceu enorme influência nos Estudos Descritivos da Tradução.

A teoria dos Memes considera que, assim como na teoria da seleção natural darwiniana, apenas os melhores tradutores / as melhores traduções permanecem. No entanto, a versão atual do livro faz ponderações quanto a essa afirmação, uma vez que só a regulari- 
dade textual de um dado fenômeno não é suficiente para alçá-lo à categoria de norma. Seriam necessários outros indicadores à parte do texto para fundamentar a caracterização de um fenômeno como norma, como a existência de provas empíricas, contraprovas, etc.

O capítulo 4, Translation Strategies (Estratégias de Tradução), traz a classificação de 30 estratégias de ordem sintática, semântica ou pragmática, cuja utilização é frequente entre tradutores. Inspiradas nas notórias estratégias propostas por Vinay e Darbelnet, estratégias são aqui definidas como "formas explícitas de manipulação textual que são diretamente observáveis no produto da tradução em si, em comparação com o texto fonte" (86). Na versão atualizada, Chesterman distingue uma série de termos dentre os quais estão aqueles que se referem a ações microtextuais e os que se aplicam à relação com o nível macrotextual. Há também a discussão sobre o que motiva o tradutor a tomar uma determinada decisão em escolher qual estratégias usar em cada situação. Essa motivação estaria estreitamente relacionada ao desejo de se conformar a uma ou mais normas, seja por razões socioculturais ou de ordem pessoal.

"Translation as theory" (Tradução como Teoria), o quinto capítulo da obra, apresenta os conceitos teóricos da tradução enquanto objeto de investigação científica. O autor adota mais uma vez o esquema de Karl Popper, através do qual se descreve o processo de aquisição da metodologia científica e a aquisição do conhecimento racional como solução para os problemas de tradução. Especialmente focado na avaliação, Chesterman propõe cinco modelos com normas bastante específicas. A avaliação retrospectiva, por exemplo, refere-se à relação de um dado texto com outro, o que acaba por refletir em considerações sobre equivalência. A avaliação prospectiva toma por base o exame do propósito do texto e o efeito que ele deve causar no seu público leitor. Por avaliação lateral entende-se a comparação entre a tradução e outros textos existentes na língua - textos paralelos ou comparáveis (130). A avaliação introspectiva tenta prescrutar a mente do tradutor e examinar 
até que ponto o tradutor pode ser considerado responsável pelas próprias escolhas tradutórias. Finalmente, a avaliação pedagógica considera os erros e, através das normas, retorna à ideia popperiana de refinamento. $\mathrm{O}$ autor afirma que traduzir é teorizar, é propor uma teoria parcial que resolva a problemática da própria tradução. Ao considerar que qualquer tradução é "uma visão do texto-fonte, a visão do tradutor" (115), Chesterman afirma que avaliar uma tradução é o mesmo que avaliar a filosofia de quem traduz. Como atualização, o autor aponta a falta de uma discussão a respeito dos procedimentos de revisão.

No capítulo 6 "The development of translational competence" (O desenvolvimento da competência tradutória), o autor se volta à teoria popperiana que sugere uma relação entre estágios da história da teoria da tradução e as fases de aquisição da competência tradutória. Designando fases pelas quais o tradutor passa em seu ofício, Chesterman aponta o iniciante na área como "novato", aquele que começa a conhecer as regras da manipulação de textos. Num segundo momento, a experiência desse aprendiz o alça à categoria de "iniciante avançado". O autor categoriza como "competente" aquele tradutor capaz de perceber a tarefa tradutória como um todo, capaz de formular um plano que possibilite a execução dessa tarefa, considerando aquilo que seja mais relevante. Quando se desenvolvem suas capacidades de resolução de problemas, o tradutor se torna "proficiente", até atingir a capacidade de reflexão e desempenho mais refinadas que o tornam um "especialista"

Em “On translation ethics” (Ética da Tradução), o sétimo capítulo, há uma abordagem das mais relevantes questões éticas do relacionamento do tradutor com o mundo e no que concerne as suas decisões durante o processo tradutório. O autor ressalta a importância dos valores éticos como a principal norma que rege o fazer tradutório. A análise dos valores éticos demonstrados nesse capítulo relaciona-se com as normas de expectativa, relação, responsabilidade e comunicação. Deste modo, Chesterman define os 
quatro valores de tradução que considera fundamentais: Clareza, Confiabilidade, Verdade e Compreensão. Clareza é um valor fundamental e para Popper é o padrão linguístico mais importante, já que 'sacrificar a clareza é enfraquecer qualquer possibilidade de uma comunicação racional' (173). O valor da Verdade substitui aquilo que historicamente tem sido diretamente atrelado ao que se define como "fidelidade" ao texto-fonte. Confiabilidade é o valor que rege a norma da responsabilidade do tradutor em relação a todas as partes envolvidas em seu trabalho. O valor da Compreensão visa minimizar os possíveis mal-entendidos que possam haver durante uma tradução e que podem até excluir um certo número de receptores. O livro também aborda a tradução emancipatória, uma noção eivada de caráter ideológico desenvolvida pela Linguística crítica, na defesa de um discurso democrático. Andrew Chesterman menciona o Translator's Charter, uma espécie de constituição internacional sobre os direitos e deveres do tradutor, especialmente no campo da ética. Na seção que acompanha a atualização desse capítulo, percebe-se o crescimento bastante considerável do escopo de tudo o que se relaciona à ética, desde a primeira publicação da obra.

Este livro configura-se como uma tentativa de encontrar uma forma mais produtiva de organizar as muitas linhas de pensamento e teorias dos Estudos da Tradução. O autor descreve uma teoria unificadora, ao propor métodos mais empíricos para assuntos considerados subjetivos dentro do universo da tradução. Para isso, uniu-se a filosofia popperiana às muitas outras visões a análises do tema. Quanto aos objetivos de ordem metateórica, teórica e prática propostos pelo autor, pode-se afirmar que ele logra êxito. Considerando sua abrangência de temas, Memes of Translation constitui uma leitura importante para todos os profissionais, estudiosos e interessados na área. 


\section{Referências}

Chesterman, Andrew. Memes of Translation - The spread of ideas in translation theory. Amsterdam/ Philadelphia: Benjamins Translation Library, 2016, 225 p.

Recebido em: 15/12/2018

Aceito em: 15/02/2019

Publicado em maio de 2019

Luciana Alves da Silva. E-mail: luciana2505@yahoo.com.br. ORCID: https:// orcid.org/0000-0002-7571-357X 